San Jose State University

SJSU ScholarWorks

Faculty Publications

$1-1-1991$

\title{
Nobody's Grandfather Was A Merchant: Understanding the Soviet Commercial Negotiation Process and Style
}

Mahesh N. Rajan

San Jose State University, mahesh.rajan@sjsu.edu

J. L. Graham

Follow this and additional works at: https://scholarworks.sjsu.edu/mktds_pub

Part of the Business Commons

\section{Recommended Citation}

Mahesh N. Rajan and J. L. Graham. "Nobody's Grandfather Was A Merchant: Understanding the Soviet Commercial Negotiation Process and Style" California Management Review (1991): 40-57.

https://doi.org/10.2307/41166660

This Article is brought to you for free and open access by SJSU ScholarWorks. It has been accepted for inclusion in Faculty Publications by an authorized administrator of SJSU ScholarWorks. For more information, please contact scholarworks@sjsu.edu. 


\title{
Nobody's Grandfather Was a Merchant: Understanding the Soviet Commercial Negotiation Process and Style
}

\author{
Mahesh N. Rajan John L. Graham
}

I

t looked strange indeed. There were two Americans with their sleeves rolled up bargaining with three Japanese sitting stiffly, and the conversation was dubbed into Russian. Instead of yes or hai, it was da and so on. The videotapes were part of two-day seminars the second author was delivering to groups of Soviet enterprise managers in Moscow in 1989. The programs had two goals. The first was to learn about Soviet negotiation styles by directly observing Soviet behavior in simulated commercial negotiations. The second goal was to help familiarize the Soviets with the American and Japanese negotiation styles, since both groups are important investors in the evolving Soviet market system. Our research and experiences in Moscow confirm that American managers dealing with Soviets today and in the future will need what Tolstoy referred to as: "The strongest of all warriors . . time and patience."

\section{Background}

Hardly a day passes without some mention in the popular media of the dramatic changes taking place in the Soviet Union and Eastern Europe. Though much uncertainty surrounds his own future, Mikhail Gorbachev's campaigns of perestroika (restructuring) and glasnost (openness) have 
greatly transformed the nature and core of global politics. Consequentially, the world has witnessed such radical events as the tearing down of the Berlin Wall and the reunification of the two Germanies, freely elected noncommunist governments in Poland and Czechoslovakia, the bloody overthrow and execution of Rumania's hard-line dictator, and the disbanding of Bulgaria's once highly feared secret police.

Speculation is no longer necessary about whether these changes mark the beginning of an irreversible process. These changes signal a shift in ideology and also herald economic opportunities for American and Western firms in hitherto closed, totalitarian nations. Dissension within COMECON, the 40-year-old system which once controlled trade in Eastern bloc countries, has caused it to lose power and subsequently has sent member countries scurrying to find new sources of capital and technology. Of these countries, the Soviet Union, because of its geographic and economic immensity, probably interests American firms the most as a potential market.

Unfortunately, economic relations between the U.S. and the Soviet Union have been overshadowed and influenced by their political discourses. Clearly, the U.S. government's historical practice of ad hoc trade policies to either help or harm the Soviets (depending on the current U.S. perspective) is a well-documented testimony to this. In the last few decades, this unfortunate condition is reflected in the fact that there is far more English language literature dealing with formal state-to-state negotiations between the Soviet Union and the U.S. than there is on commercial trade negotiations between the two. Corporate America suffers from a paucity of knowledge about Soviet culture and the logic of Soviet negotiation processes, coupled with a general suspicion and skepticism of the Soviets rooted in the heightened political conflicts of the past seventy years. Ideologically driven by stereotypical images of their counterparts, American business executives generally find negotiations with the Soviets tedious and cumbersome, and such negative experiences further fuel fallacious thoughts and actions. Given the ideological differences between the U.S. and the Soviets, as well as the fragile existence of economic trade between the two, it is not surprising that Americans lag behind Europeans and Japanese in venturing into business in the Soviet Union. As their respective views shift to be less confrontational, however, new opportunities for cooperation may emerge. Frustrations may be lowered, business endeavors facilitated, and economic ties strengthened as both sides gain insights into one another's cultures and the logic of their negotiation styles.

Our own studies investigated similarities and, more importantly, differences in the processes and outcomes of negotiations in the U.S. and the Soviet Union. For instance, in both cultures a cooperative and interpersonal approach tended to lead to higher satisfaction for the partners-a critical factor for establishing long-term business relationships. However, a problem-solving approach yielded higher profits for individual negotiators among the Americans, but a similar approach among the Soviets resulted 
in lower profits. Thus, the cooperative approach may yield positive results when used by Americans in negotiations with their fellow countrymen, but it may not work in the same way with Soviet negotiators. Conversely, a competitive or distributive approach which tends to work among Soviets may not achieve comparable results with American business executives. Based on our most recent studies, these differences appear to be crucial and fundamental, hence they must be acknowledged and examined to develop normative models of negotiations for the two countries. For negotiations to be successful, both sides must be cognizant and sensitive to how their differences can precipitate problems.

A point of caution - the kind of Soviet negotiator you will be sitting across from may be quite different from even last year. Until recently, only officials from Foreign Trade Organizations (FTOs) participated in commercial negotiations with Western firms. Though representatives and managers of Soviet state enterprises were allowed to be present at such meetings, foreign trade (i.e., imports and exports) was under the exclusive control of the few dozen FTOs. However, since April 1988, more than 5,000 Soviet state enterprises have applied for direct trading rights - meaning Western managers can now call on Soviet buyers and sellers directly, thus avoiding the previous bureaucratic channels. Additionally, provinces such as Russia and Lithuania are threatening to conduct trade autonomously and outside of the Union of the Soviet Republic.

Moreover, most of the previous literature on the Soviet negotiation style is based upon observation of political negotiators and to a lesser extent FTO personnel. However, several scholars have suggested that very basic driving forces influence traits and behaviors of Soviet negotiators across all negotiation situations - commercial, political and arms reduction talks. ${ }^{2}$ This point is best articulated by Beliaev, Mullen, and Punnett, who state:

\footnotetext{
All individual or collective actions of Soviet negotiators are overwhelmingly influenced by the state and the state ideology. The emphasis on individual behavior, which is culturally "in the blood" of Americans, leads to a tendency for them to underestimate the pervasiveness of the Soviet state in the consciousness and behavior of every Soviet person. It is necessary to realize that the Soviet people take virtually no step, in their public or private lives, which does not depend on the state. ${ }^{3}$
}

Therefore, in our discussion of the Soviet negotiation process and style, relevant material from the literature regarding arms and political negotiations is also considered.

Finally, though dramatic changes have been taking place in the structure of the Soviet economy, it certainly does not mean that the Soviet Union is on the verge of becoming a normal market economy. While commitment to the party or state ideology may be on the wane, we feel that it will be perhaps generations before such fundamental values can be eradicated, if at all, from the culture and lifestyle of the Soviet people. Hence, institutional 
controls (such as price-fixing) and non profit-maximizing goals will remain, thereby influencing Soviet and American negotiators to respond differently to economic stimuli.

\section{The Soviet Negotiation Process}

Lengthy - Negotiations involving Soviets can last for a few years before an agreement is reached. Indeed, McDonalds of Canada first started talking to the Soviets in 1976. The primary reason for long, drawn-out negotiations is that often they are divided into two sequential stages: technical and commercial. The technical stage may or may not include the end-user and spans issues such as technical requirements, product specifications, and technology considerations. Only after its successful completion, which can take a year, will the Soviets discuss the financial aspects of the deal. Then the commercial stage, often involving representatives from the Foreign Trade Organizations and from Soviet financial institutions, generally takes a like amount of time. There are other factors which also slow down the negotiation process: overlapping and conflicting ministerial divisions, multiple layers of decision making, centralized planning, tenuous lines of internal communication, and intense specialization (which results in no one individual having complete information or authority). Further, the Soviets may prolong the technical negotiation stage to acquire as much knowledge of Western technology as possible. Finally, they, like managers in most foreign countries, may also deliberately dally to gain concessions by taking advantage of the renowned "eagerness" and "impatience" of the Americans. Alternatively, the Soviets can hasten negotiation processes when the object of the negotiations has a high priority to them or when they are the seller.

Location-Connected closely with timing is location. And there's simply no ideal place to negotiate with a Soviet, at least from the standpoint of the typically impatient American. For example, we know of one American firm whose managers travelled to the south of France (a neutral location) to close negotiations with a Soviet customer on a multimillion-dollar natural gas pipeline equipment deal. The Soviets arrived and, true to their reputation, refused to budge on any provision. The American negotiation team was quite discouraged until it occurred to them that the Soviets weren't in a hurry for several reasons. Negotiation tactics, yes, but the Soviets were also simply enjoying their stay on the Mediterranean. So the Americans, with wary permission from their headquarters, decided to slow things down themselves. The two sides would meet at 10 a.m., quickly decide that nothing could be resolved, then agree to meet the next morning at $10 \mathrm{a} . \mathrm{m}$. Then both sides would hit the golf links or the beach or get some paperwork done. This routine went on for one, two, three weeks. Finally, in the fourth 
week, the Soviet side began making substantial concessions. The Soviets were not in a position to return to Moscow without a signed contract after a month in southern France!

So, if you bring the Soviets to the U.S. or to a neutral location, they'll take their time. However, negotiating in Moscow is also a bad option. At this writing, the living conditions for visiting foreign executives are among the worst in the world. Americans will be even more impatient than in other foreign cities because Soviet accommodations lack the "creature comforts" typically available at the local Hilton. Moreover, in Moscow, the dearth of secure communication facilities makes negotiation processes very difficult. Perhaps the tongue-in-cheek comment about Reykjavic being the ideal location for a U.S./Soviet summit has some truth in it- "Nobody enjoys visiting Iceland."

Difficult-Characteristically, Americans and Soviets have different priorities and ideological orientations, making negotiations between them arduous. Americans primarily are concerned with bottom-line profits and personal gains, while Soviets are more apt to be driven by ideological goals and collective gain for their organizations. Many Soviets may be unfamiliar with Western management concepts and practices: "the word market has no equivalent in the Russian language". and "some Soviet managers are even hazy about the meaning of the word profit"s [emphases added]. In fact, the chairman of the Central Council of Trade Unions in the Soviet Union states that the Soviet "people discuss the market without even knowing what it is. We know more about space research than we do market research." ${ }_{6}$ This knowledge gap tends to further aggravate American business executives. Moreover, the Soviets view negotiations as tests of potential suppliers and, hence, intentionally complicate and prolong them, believing that companies which survive such ordeals are likely to be better partners than firms which drop out of the talks. Finally, Americans often find the Soviets' insistence on favorable credit terms exasperating, which contributes to the overall difficulties of negotiations.

Countertrade Issues-Issues of countertrade play such a significant role in the negotiation processes that they warrant separate mention. Nonmonetary compensation schemes are explored by the Soviets for all but the highest priority items. The countertrade arrangements they propose can range from simple barter to highly complex product buy-backs and threeparty switching agreements. In the wrap-up of negotiations, after agreements have already been reached regarding such things as price, quantity, and time frames, the Soviets propose such countertrade. Besides being concerned with the inconvertibility of the ruble, the Soviets are driven by two other motives. First, countertrade allows them to conserve their much 
treasured, relatively limited hard currency reserves. Second, but of more importance, it helps them penetrate foreign markets without having to develop marketing skills and with no outlay for distribution facilities. Thus it should not be surprising that Soviets prefer to deal with firms which are agreeable to countertrade transactions. They probably assume that direct exporting will become easier once world markets become accustomed to Soviet products. If the opposite party insists on a cash-only method of payment and if there are no alternative suppliers or forms of agreement, the Soviets still introduce countertrade proposals as bargaining tools to gain additional concessions.

Generalized Warranties and Written Contracts-Soviet buyers attempt to get the most generalized warranty agreement possible from the seller. Hence, they downplay American concerns about liabilities arising from non-specific warranties and unforeseen contingencies such as Act of God (force majeure) provisions. However, they have been known to hold the other party responsible for delays or failures even when the factors for noncompliance were beyond that party's control. Business executives who do not specifically spell out in writing the terms of responsibility and liability in the warranty section of their agreements will be rudely awakened by how boldly the Soviets attempt to exploit the vagueness of the agreement. All contracts between American firms and Soviets are generally governed by Soviet law, which does not recognize oral agreements as binding, so business deals are not consummated until all concerned parties have signed the documents. Written contracts then supersede all previous unwritten agreements and implicit assumptions, which explains why Soviet negotiators introduce countertrade issues so late in the process. Further, the Soviets insist on writing down every other aspect of the transaction - things taken for granted in Western nations such as verbal confirmations of receipt of goods and telephone reorders-except the warranty section.

Peculiar Twists - When negotiations have been conducted in the Soviet Union, they have been marked by Soviet acts which Americans have generally found both unusual and disconcerting, to say the least: long-scheduled meetings were cancelled; agenda and venue were changed frequently; large orders were mentioned casually and just as casually denied; negotiation leaders were switched without informing the Americans. Americans who have dealt with the Soviets are divided on whether such Soviet actions are deliberate and hence unfair tactics, or if such developments are systemrelated and therefore not only inevitable, but also legitimate. This issue continues to be a controversial debate as neither claim has been definitively proved. It behooves U.S. business executives, however, to be alert to and prepared for such peculiar developments. 
Protocol/Symbolism-Soviets are so sensitive to protocol issues that, in addition to preferring that concerned parties deal directly rather than through intermediaries, they usually appoint negotiators comparable in position to the other party's representatives. They seem to gauge a firm's sincerity about doing business with them by the rank and status of the firm's negotiator and interpret simple acts (such as frequent trips to the Soviet Union by top executives, the opening of offices in the Soviet Union, and participation in trade fairs and exhibits in or sponsored by the Soviet Union) as symbolic representations of friendship and as acknowledgement of the worthiness of the Soviet market. Rival bidders have found that the firm which spends the most time, effort, and money wooing the Soviets often emerges from negotiations with the written contract.

Continuity-Perhaps the most remarkable aspect of the negotiation process is the Soviets' perspective of continuity. Because they prefer to do business with those with whom they have satisfactorily interacted in the past, the Soviet negotiators pay extra attention to a firm's reputation and capabilities during the first encounter. Successful initial contracts may pave the way for even more profitable future ventures as the Soviets become more cooperative and trusting of their foreign business partners and eventually voluntarily mitigate some of the hazards their partners find so thwarting.

\section{The Soviet Negotiation Style}

Secretive-Perhaps Winston Churchill put it best: "I cannot forecast to you the action of Russia. It is a riddle wrapped in a mystery inside an enigma." The Soviet penchant for secrecy becomes apparent immediately to negotiators from other cultures, especially from Western nations. Isolation from and distrust of the rest of the world generally lead the Soviets to reveal very little information about themselves or their motives to outsiders. From an organizational and administrative perspective, in a bureaucratic monolith such as the Soviet Union, officials become tight-lipped because information is a source of power and upward mobility and is guarded jealously.

Risk-Averse-Soviet negotiators' fears of being reprimanded and/or removed from privileged positions for unsuccessful and unfavorable contracts force them to have a basically conservative outlook and behavior. Moreover, the fundamentally deterministic nature of the (still largely) centralized planning system of the Soviet Union, with its history of ideological blindness to capitalistic management theories, encourages Soviet negotiators to be extremely wary of overstepping official bounds in their interactions with Western managers. 
Detail-Oriented-The complexity of the Soviet bureaucracy, combined with the Soviets' risk-averse nature, forces their negotiators to pay great attention to even trivial and extraneous details. Also, to win the approval of their superiors, Soviet negotiators must be sure that they have not overlooked the minutest of details. In fact, it is said that such attention to detail is expected from Soviet negotiators as evidence of their integrity and commitment to the socialist ideology. Therefore, on several occasions Soviet negotiators have been known to expend a great deal of time and effort negotiating the picayune details in the "fine print" of contracts after generally agreeing to ventures worth millions of dollars.

Unsympathetic-The Soviets are known to interpret the terms of a contract literally and will brook no excuses from the other side for delays or failures to meet contractual obligations. There have been a few instances in the past when American firms have been penalized by the Soviets for nonperformance even though the factors causing non-compliance were directly controlled by the Soviets. American business executives should make sure that they take nothing for granted and that all conditions which determine the fulfillment of their obligations are specified in writing. Though they are irritated by the Soviet negotiators' dogged attention to detail, seldom do American business executives realize that their own interests are protected and enhanced by the highly detailed agreements that result from such negotiations.

Uncompromising-Perhaps the most conspicuous aspect of Soviet negotiators at the bargaining table is their uncompromising attitude. Scholars as well as American business executives have frequently described them as tough, hard, confrontational, inflexible, competitive, stubborn, and rigid. Their behavior is said to reflect either the rigidity of their organizational structures, their ideologies, their culture, or some combination of the three.

Economic plans drawn up by the upper echelons of Soviet bureaucracy generally leave little authority or room for Soviet representatives, who are usually from the lower and middle levels of the organization, to maneuver at the negotiation table.

From an ideological standpoint, the Soviets view the negotiation process as neither a means of achieving higher profits for their organization nor as a vehicle for furthering personal goals - unlike Americans. Instead, to the Soviets the negotiation process represents an opportunity for "right" (their world view) to succeed over "wrong" (the American perspective); thus they assume inflexible, uncompromising, conflictual stances.

According to two experts on the Soviet Union, Vladimir and Victorina Lefebvre, Americans and Soviets are governed culturally by two different 
"ethical systems." ${ }^{8}$ Western cultures are dominated by an ethical system in which the behavior of individuals who seek compromises to resolve conflicts with their adversaries is considered positive. However, Soviets are governed by a different ethical system in which it is positive for individuals to create new conflicts with adversaries and to exacerbate existing ones. The Lefebvres further contend that the very word "deal" itself has negative associations in the Russian language, because anyone seeking compromises is considered cowardly, weak, and unworthy. After observing the interactions of Soviet schoolchildren with Western tourists near the Kremlin, Professor Weigand commented that "a single stick of Juicy Fruit will get a foreigner a small piece of colored ribbon, but a whole package-after some tough bargaining _ can win a bronze-like medal of Marx and Lenin." His observation of children seems to corroborate the Lefebvres' theory that such rigidity on the part of the Soviet negotiators in their interaction with outsiders may be a product of the Soviet culture and thus may actually be a national trait, rather than due solely to bureaucratic and ideological forces.

Indeed, based upon our own studies of the Soviet negotiation style, they seem to by nature take a much different approach to commercial negotiations. Perhaps Alexander Arefiev, CEO of INFORCOM (an important Soviet management development firm), puts it best: "My biggest problem is convincing my Soviet clients to take a cooperative approach with Westerners." That is, by nature, Soviet executives will take a competitive or adversarial approach in negotiations with Americans. Creative, win-win solutions don't fit the Soviet psyche well. So cooperation and commitment to open and honest information exchange must be imbued.

Professor Oleg Vihansky, head of Moscow State University's Department of Management, provides a deeper cultural explanation when he contrasts the Soviets' approach to business partnerships with that of the Japanese. He suggests that the Japanese are the best at searching for creative bargaining solutions - making the pie bigger before it is divided. Traditionally, Soviets see negotiations as more a zero-sum activity - they tend to worry about how the pie is to be divided with little thought to increasing its size. Rooted deep in the Soviet psyche is the idea that one person's success is always at the expense of someone else.

One aspect of our studies of negotiation styles around the world directly supports Professor Vihansky's analysis. Not only have Americans and Soviets participated in our negotiation simulations, so have almost 800 businesspeople from twelve other cultures. (Of course, materials were translated in each case and bargainers used their own native languages.) The simulation allows for creative bargaining solutions - it is not a zerosum game; the "pie" can be made bigger via cooperative negotiation strategies. As Vihansky would predict, the Japanese have been the best of all the cultural groups at making the pie big, that is, at maximizing joint profits. The bargaining solutions achieved by the Americans were near the average 
for all fourteen groups. The Soviet outcomes were quite close to the bottom, a finding which confirms and clarifies the picture that Soviets are, by nature, uncompromising.

Finally, we mentioned in an earlier section that Soviet managers are "hazy about the meaning of the word profit." The Soviet word pribyl (meaning "for profits") implies exploitation; that is, profits are always at someone else's expense. Alternatively, the English term profits can imply exploitation but also often implies creativity. Indeed, this difference between the two languages in meanings of the term profits is a reflection of the more fundamental differences in the two social and commercial systems. When you say "profits," your Soviet counterpart thinks "exploitation," not "creativity."

Manipulative-As most commercial negotiations with Soviets take place in the Soviet Union, the Soviets can and do manipulate negotiation processes in order to gain better terms for themselves. Three of the more popular techniques employed by the Soviets as tools of bargaining leverage are described as follows:

- They will negotiate the price at the initial stages of the process under the pretext of placing a large order. Once they have wrangled the best possible price from the suppliers, the Soviets will then, in addition to bringing up countertrade demands, require either additional concessions (such as service contracts or personnel training programs) or will reduce the volume of their purchases while demanding the previously agreed upon price.

- "Whipsawing" is another favorite manipulative technique of the Soviets, wherein they carry on negotiations with several competing firms simultaneously. They then use selective information from their interaction with one firm in their negotiations with another, pitting the rival firms against each other, thus obtaining the most self-serving contract. On occasion, in not-too-subtle demonstrations of their relatively superior bargaining position, the Soviets have made arrangements for executives from rival firms to stay at the same hotel at the same time.

- An unknown Soviet bureaucrat will enter the room during actual negotiations and fly into a rage at the other side for treating the Soviet negotiators with disrespect and distrust. Expecting the American negotiators to be unnerved by this "tirade," the Soviets will then indicate a willingness to forgive the Americans in exchange for additional concessions.

While many American business executives would consider such acts by the Soviets unethical and unprofessional, these techniques may appear perfectly rational and legitimate in the eyes of the Soviets. ${ }^{10}$ Given that different "ethical systems" govern the two cultures, such a difference of opinion 
should be regarded as neither surprising nor unusual. Based on their empirical study of Soviet emigrants' and middle-class Americans' responses to several hypothetical situations, the Lefebvres concluded that while "the majority of former Soviet citizens consider it acceptable to use bad means to achieve good goals . . . the majority of Americans disagree with this." Our own more recent comparisons of American and Soviet managers' attitudes strongly confirm the Lefebvres' findings.

Loyal-Though most of the previously discussed material presents the Soviets in an adversarial and combative light, the authors certainly do not mean to imply nor to advocate that American firms should avoid the Soviet market. The Soviet Union is a highly desirable and potentially profitable market, as has been proven by the experiences of firms such as Occidental Petroleum and Pepsico. However, the development and nurturing of personal relationships with the Soviet negotiators are critical prerequisites to establishing good business relationships with the Soviets. The Soviet emphasis on interpersonal relationships and its effect on the outcome of negotiations is perhaps rivalled by only a few cultures, if any. Organizational constraints, ideologically driven fear and suspicion of outsiders (especially of Americans), and a fundamentally risk-averse nature make it absolutely imperative for the Soviet negotiators to sign contracts only with firms (and executives) they feel they can depend upon. Personal relationships based on mutual respect and understanding, combined with a history of satisfactory business transactions, are crucial for successful ventures with the Soviets. Efforts on the part of the American executives to acknowledge and gratify these requisites are rewarded with trust and loyalty by the Soviets, thereby perpetuating the Soviet preference for "continuity" in their commercial transactions with foreign firms.

Reliable-Given the overall difficulty and frustrating nature of the Soviet negotiation process and style, a surprising characteristic of the Soviets is that until 1990 they were extremely reliable and always honored their contractual commitments. Even more impressive was the impeccable record that the Soviets have had, until now, in fulfilling their financial obligations, to the extent that some American suppliers wish their Western customers were equally prompt and conscientious in their payments. Last year in Moscow, John Minneman, Chase Manhattan's vice president/representative in the USSR, told us about his Soviet banking counterparts: "They're sophisticated and tough, but they never lie and always pay on time." An observation by another expert on international trade succinctly sums up the nature of the Soviet negotiation process and style: "Although the Soviets drive a very hard bargain in contract negotiations, they will abide faithfully by its provisions, and expect the other party to do the same. They have an excellent record in honoring their financial commitments." 12 
However, the picture of the Soviets as reliable fiscally has become somewhat clouded in recent months. Several Western concerns have reported slow payments by Soviet customers. State-backed transactions at this point are not the problem, but some Soviet enterprise and foreign trade organizations (FTOs) are having trouble meeting current obligations and are not being bailed out by the Bank of Foreign Economic Affairs as was customary in the past. No one has yet defaulted,,$^{13}$ but some American firms have stopped shipping to Soviet clients. In fact, most Western analysts blamed the problem on confusion caused by the reshuffling of Soviet officials as part of President Gorbachev's perestroika and glasnost programs. However, one top-ranking Soviet official, addressing a symposium in the United States, allayed Western concerns about the Soviets defaulting on their payments by stating that "we do pay our bills, and we don't rob from Peter to pay Paul." ${ }^{14}$ Moreover, the Soviet Union has begun depositing large amounts of gold with Western banks as collateral for loans; and to help cover overdue bills abroad, it is also drawing on Moscow's hard currency reserves and setting up an internal collection agency. ${ }^{15}$ These corrective measures, taken by the Soviets to restore and protect their once excellent credit rating, should provide incentive and reassurance to foreign firms seeking new or increased trade opportunities. However, Americans must clearly recognize that in the long run, as free enterprise comes to the USSR, so will concomitant business failures and defaults.

\section{Some Tips for American Managers}

In interacting with the Soviets, besides profiting by a general awareness of the culture and the complex bureaucratic governance structure of the Soviet Union and their effects on the negotiations, American business executives may find it beneficial to adopt the following strategies.

Be Cautious-While tremendous changes are taking place which represent a huge array of opportunities for American firms, the risk and uncertainty surrounding perestroika cannot be ignored nor trivialized. Mikhail Gorbachev is a charismatic leader who definitely has set the wheels of change in motion, but whether these reforms will last and lead to greater economic standards, only time will tell. Investing large amounts of capital and technology in a society governed by such a different ideological and political structure is perilous, as painfully illustrated in China last year. The fact that trade with socialist countries is subject to government intervention based on the political climates, particularly of the U.S., warrants a cautionary approach to the Soviet market.

Be Open-Minded-American managers need to find ways to shed biases rooted in decades of selective and politically motivated information and 
images of the Soviet Union. These images hinder objective evaluation of the viability of the Soviet market and make negotiations with the Soviets formidable. They also increase the chances of American firms losing out to more impartial competitors. In the long run, emphatically ruling out the viability of the Soviet market on the basis of ideological considerations may not be good business. Remember, the Soviets prefer dealing with longknown business partners.

There are no Dun and Bradstreet services for the Soviet Union. The only way to size up a potential partner is by relying on a network of acquaintances that you have established through a corporate presence in the country. You must take the time to learn the market and the people-there's just no quick way.

Be Culturally Sensitive-Centuries of isolation and oppression have not only instilled a general fear and suspicion of outsiders, but also have forced the Soviets to rely solely on their cultural roots for the inner strength and ardor that typifies them. In spite of such onerous backgrounds, the Soviet people are an exceptionally proud and patriotic people. So much are they influenced by and committed to national and collective interests that they almost always relegate personal gain and welfare to a secondary status in their thoughts and behaviors. They appreciate and respect foreigners who are knowledgeable of and empathetic to their historical and cultural origins. Further, acquiring such knowledge not only helps American business executives understand Soviet citizens, but also helps them make the adjustments necessary for successful business relationships with them.

Unlike citizens in other countries, Soviets have no collective memory of free enterprise. In Eastern Europe and even the People's Republic of China and North Korea, young people have grandfathers who were merchants before World War II. Not so in the Soviet Union-the communist tradition goes back to 1917 , so no Soviet's grandfather was a merchant.

Be Patient-Any visitor to the Soviet Union, on business or as a tourist, immediately is aware of the incredible complexity and size of the Soviet bureaucracy. The assorted restrictions set by this monolithic and hierarchical administrative structure on Soviet negotiators force them to behave in ways that frustrate American executives. Additionally, current changes in the governance structure have removed the exclusivity of the well-trained and highly skilled FTO officials in dealings/negotiations with foreign corporations. Hence, state enterprise managers and middle-level officials who are unaware of Western management concepts have been thrust into negotiation settings, making these situations painful and slow for both parties. A key point for Westerners sitting at the table with Soviets to remember: Be both cognizant and patient with the traditional Soviet approach; "help" your partners learn to look for ways to make the commercial pie bigger for both sides-it's simply not their natural style. Even if the longevity and arduous- 
ness of the negotiations are of a deliberate nature, American executives can, by exhibiting atypical patience, pave the way not only in initial contracts, but also in opening up future profitable opportunities.

\section{Exchange Views about Negotiation Processes-Caution is suggested} here. One Soviet executive told us that what bothers him most about Americans is their arrogance. He said that "Americans take a teaching approach" while "Japanese listen cordially." While it is true that Soviets are willing to learn directly about the American free enterprise system in management seminars, they may resent being "taught" by their business partners. In negotiations, we recommend an information exchange or mutual teaching approach. It is all right to say, "This is the way things work where I come from," only if you've first asked how things work in the USSR.

During your get-acquainted meetings or dinners, you may want to ask your counterpart how negotiations typically proceed in the Soviet Union. That is, you might verify the information we provide here about the Soviet negotiation style and process. Tell them this is what you have been reading about the Soviet approach, and then ask, "What do you think of Rajan and Graham's ideas?"

Then you will be in a position to say things like, "In the West we try to be creative in business negotiations by exchanging information freely-we try to make the pie bigger before we cut it up." Show an interest in their system and its transformations before you begin giving advice. And get these things straightened out before you begin your specific task-related discussions.

Be Flexible - A rigid adherence to planned strategies and goals may not be the best negotiation stance for American firms in the Soviet Union. One area of negotiations where flexibility and a willingness to consider other options are particularly important is the area of credit and payment provisions. Though American managers are indoctrinated by the free market and their corporate structural orientations to have a "hard-currency-transactiononly" attitude, it is not profitable to apply this in negotiating with the Soviet Union. Professor Yoffie observed that "in a buyer's market countertrade can be especially important. When price, technology, and quality are comparable, willingness to countertrade often separates winners from losers." 16 Therefore, American managers, if they wish to compete successfully for the Soviet market with Japanese and European competitors (who have accepted non-monetary compensation agreements somewhat more enthusiastically), need to consider seriously the opportunities of trade without money.

Hopefully, other American firms and their executives can learn something from the Pepsico example. Obviously, Pepsico Inc. is quite satisfied with its long-standing countertrade arrangements with the Soviets-Pepsi-Cola bartered for Stolichnaya Vodka and scrap iron from moth-balled Soviet 
battleships. They have recently agreed to a dramatic expansion of their operations in the USSR, including continuing provisions for countertrade.

Right now most American managers seem to suffer badly from what we call "allassophobia," or "fear of countertrade." ${ }^{17}$ Recently, we had lunch with an executive of a local high-tech firm who was about to depart for the Soviet Union. We asked him how he planned to handle his Soviet customer's probable countertrade proposals. His response was a classic display of acute allassophobia: "We won't do countertrade. Our company has a policy against it." Within ten days of our luncheon, a major competitor announced being awarded that very bid, and, of course, the deal included countertrade provisions.

Allassophobia is a serious malady which impairs American firms not only in Soviet trade but also in world trade generally. Despite the fact that 20 to 30 percent of world trade is financed via countertrade, American financial institutions ignore its key importance. Alan Shapiro reserved only three pages for a discussion of countertrade options in his very popular textbook on international finance. The number crunchers on Wall Street fear what they cannot easily measure, thus countertrade is ignored in textbooks and consequently eschewed in American board rooms. The key lesson here is that avoiding countertrade as a matter of corporate policy, as so many U.S. companies do, accomplishes nothing more than tying the hands of your negotiators. Certainly your Japanese and European competitors do not suffer from allassophobia.

Finally, countertrade may be another way to hedge against potential hard currency payment problems. Who can predict the availability of hard currency in the USSR? As we mentioned, recent signals suggest that the USSR may be reaching the limit of its currency reserves. Thus, countertrade deals should be examined and considered, because they may be the most attractive options in the future.

Have a Long-Term Orientation-In any nation burdened with a stagnant or declining economy and lacking the internal capability to develop its own untapped potential, investments take a long period to come to fruition, if they mature at all. Though they are somewhat inappropriate, the characteristically short-term concerns of corporate America may succeed to some extent in other countries with private sector industries. In a non-market economy like the Soviet Union, however, the probabilities of ventures with such orientations succeeding are rather infinitesimal. The Soviets (and the other Eastern European countries) desperately need and are looking for Western firms that are willing to invest in critical industries in their country, transfer much needed technology, train their labor force and managers, accept noncash and/or lower cash payments, and play an invaluable overall role in helping them reform and develop the Soviet economy. While initially these adjustments may be rather difficult, the subsequent goodwill of the Soviet people and favored access to the tremendous potential of the Soviet 
market would be the rewards for American corporations that make the transition.

West Germans and South Koreans, in addition to the Japanese, are taking the necessary long-term approach to the Soviet market. Consider the comments of Alfred Herrhausen, former CEO of Germany's biggest bank, regarding Deutsche Bank's investments in the USSR: "It will take at least two generations. One generation is necessary to be willing to introduce freedom, but it will take the next to figure out how to make economic use of its benefits." ${ }^{18}$ Also, the fact that both West Germany and South Korea have either announced or are considering loans to the Soviet Union attests to the long-term orientations of these two countries. ${ }^{19}$ Recently, Korea's Daewoo Motor Company gave a Soviet ministry fifty automobiles-a $\$ 250,000$ or so investment towards future sales and goodwill.

Moreover, while many Western firms have halted shipments to the Soviet Union in response to the unusual delays in payments, the Japanese have taken a different approach. Several major Japanese trading houses, while continuing deliveries to the Soviet Union, have submitted export insurance claim notices to their government. (According to some analysts, the Japanese companies' low profile on this problem is intentional as they don't want to harm future trade prospects.) "They're being cautious," said Kazuko Motomura, an official with the Institute for Soviet and East European Economic Studies (a research organization set up by traders who do business with Eastern Europe), "But they're also thinking about the promising possibilities of the market in the future." ${ }^{20}$

Nissho-Iwsai (a major trading company), despite notifying the Japanese government about delays in Soviet payments for its steel and chemical products, confirmed that it still intended to participate in a consortium that is involved in a 38 billion yen ( $\$ 239.4$ million) project to build three compressor plants in the USSR. "We think that the Soviet Union will definitely make the payment," said Tetsuya Ouishi, an official in Nissho-Iwsai's public relations division. ${ }^{21}$

Finally, take a ride up the elevator at the World Trade Center (Sovin Center) in Moscow sometime. There you'll find offices of Chase Manhattan (17th floor) and Bank of America (16th floor), the latter with no executive permanently in Moscow at this writing. But on the way up, the elevator will undoubtedly be crowded with Japanese in blue suits, a few of whom will exit at the Mitsubishi floor, then the Mitsui and Sumitomo floors, and so on.

\section{Conclusions}

The pace and nature of change in the Soviet Union is such that many American perceptions and opinions of the Soviets, and perhaps some of the contents of this article, have become and are becoming increasingly obsolete. While it certainly is not an exhaustive account, we hope the above discussion provides American business executives a general insight into the 
Soviet negotiation process and style. If this article does nothing more than create an awareness among American managers of several key issues which contribute to the difficulties of negotiating with the Soviets and of appropriate and possible adaptations which may lead to many profitable ventures in the Soviet Union, we consider its purpose achieved. In spite of the many obstacles, economic trade will be enhanced if Americans gain a better understanding of the Soviet peoples' history and culture. Also, the ambassadorial efforts of business leaders like Armand Hammer and James Giffen are indeed commendable and should be encouraged. Other events are encouraging: the formation of the American Trade Consortium by six major corporations (including Chevron and Kodak) and its signing of an agreement with the Soviet Foreign Economic Consortium; the recent signing of a trade pact by officials from both countries which could lead to trade worth about $\$ 15$ billion; and the passing of the "private property" law by the Soviet legislature in March 1990. Hopefully, these are milestones, not merely token symbolic representations, and depict the foundations of greater and more stable economic cooperation between these two great nations. In his address to the ninth annual meeting of the USSR Trade and Economic Council, President Gorbachev pointed out that "if we are to have genuinely stable and enduring relationships capable of ensuring a lasting peace, they should be based, among other things, on well-developed business relations." ${ }^{22}$

Without exception, the Soviets and Americans we talked to emphasized the necessity in U.S.-Soviet trade for developing personal relationships, relationships which persist beyond political change and ideological differences. Indeed, such personal relationships can cause political change. If American business leaders wish to influence Soviet politics, they mightinstead of contributing to the political campaigns of favorite Republicans or Democrats in the U.S. - invest in business partnerships in the Soviet Union. Incentives for peace can best be created if Americans and Soviets understand one another on a personal basis. Indeed, Kipling's lines remain quite pertinent today:

Oh, East is East, and West is West, and never the twain shall meet,

'Til Earth and Sky stand presently at God's great Judgment Seat;

But there is neither East nor West, border, nor breed, nor birth,

When two strong men stand face to face, though they come from the ends of the earth! ${ }^{23}$

\section{References}

1. Leo Tolstoy, War and Peace, book X, chapter 16.

2. Leon Sloss and Scott M. Davis, "The Pursuit of Power and Influence through Negotiation," in Hans Binnendijk, ed., National Negotiation Styles (Washington, D.C.: Center For The Study of Foreign Affairs, Foreign Service Institute, U.S. State Department, 1987); Andreas Von Czege, "Soviet Negotiating Tactics in Trade with the West," Soviet and European Trade, 19 (Spring 1983): 32-54. 
3. Edward Beliaev, Thomas P. Mullen, and Betty Jane Punnett, "Understanding the Cultural Environment: U.S.-U.S.S.R. Trade Negotiations," California Management Review (Winter 1985), pp. 100-112.

4. John J. Pialka, "Soviet Bottom Line Is That Few People Know What One Is," Wall Street Journal, April 15, 1989, p. A13.

5. Peter Gumbel, "Western Money, Technology, Fall on Infertile Soviet Soil," Wall Street Journal, December 1, 1989, p. A16.

6. "Soviet Market Reform Will Be Put to Voters," Los Angeles Times, May 24, 1990, p. A1. The reader should note that languages adapt to reflect changing cultures. In Russian there has always been a word for a place where goods are bought and soldrynok. However, its meaning is quite narrow compared to the English "market." Indeed, the English term can be either a noun (as in a place) or a verb (as in an activity). Victorina Lefebvre tells us that only during the last year have the Soviets directly adopted the term "marketing" when they mean the activity in the Western sense.

7. Winston Churchill, radio broadcast, October 1, 1939.

8. Vladimir A. Lefebvre and Victorina D. Lefebvre, Soviet Ways of Conflict Resolution and International Negotiations, vols. 1 and 2 (Irvine, CA: School of Social Sciences, University of California, Irvine, 1986); Victorina D. Lefebvre, Ethical Features of the Normative Hero in Soviet Children's Literature of the 1960s-70s Studies of Cognitive Sciences, 20, School of Social Sciences, University of California, Irvine, CA, 1983.

9. Robert E. Weigand, "International Trade Without Money," Harvard Business Review (November/December 1977), p. 28.

10. The reader will note that in their popular book on negotiation, Getting to Yes, Roger Fisher and William Ury specifically warn about Americans taking such approaches.

11. Lefebvre and Lefebvre, op. cit.

12. Sondra Snowdon, The Global Edge: How Your Company Can Win In The International Marketplace (New York, NY: Simon and Schuster, 1986), p. 376.

13. Laurie Hays and Peter Gumbel, "Soviet Concerns Falling Behind in Paying Bills," Wall Street Journal, March 6, 1990, p. 1.

14. "Plan on Paying Overdue Bills Set by Soviets," Wall Street Journal, May 23, 1990, p. A20.

15. Neil Behrmann, "Soviets Deposit Gold in Western Banks As Collateral for Easing Cash Squeeze," Wall Street Journal, June 4, 1990, p. A3.

16. David B. Yoffie, "Profiting from Countertrade," Harvard Business Review (May/June 1984), p. 9.

17. Theodore Brunner (Director of Thesaurus Linguae Graece, a data bank of ancient Greek texts at the University of California, Irvine) helped coin the term by combining the ancient Greek words allassein (to barter) and phobia (fear).

18. Daniel Burnstein, Los Angeles Times, December 3, 1989.

19. "A Loan from South Korea," Wall Street Journal, June 1, 1990, p. A12; and Ferdinand Protzman, "Bonn to Prop Up Kremlin Reforms with \$3 Billion Loan Guarantee," New York Times, June 23, 1990, p. A1.

20. “Japanese Traders Informing Tokyo Soviet Bills Unpaid," Wall Street Journal, May 2, 1990, p. A11.

21. Ibid.

22. Mikhail S. Gorbachev, "Remarks on U.S.-U.S.S.R. Trade," Harvard Business Review (May/June 1986), p. 56.

23. Rudyard Kipling, "The Ballad of East and West," 1889. 
Copyright of California Management Review is the property of California Management Review and its content may not be copied or emailed to multiple sites or posted to a listserv without the copyright holder's express written permission. However, users may print, download, or email articles for individual use. 